\title{
Ali Oğuz Diriöz* \\ Overview of Relations between Turkey
and the Gulf Cooperation Council (GCC)
}

\begin{abstract}
In 2008, Turkey became the first country that started an institutional mechanism of strategic dialogue with the GCC. This was also important for cooperating in the fields of transport and energy security. GCC states are among wealthiest in the Middle East and Turkey has a strong economic and industrial base, which makes them complementary partners. Therefore their cooperation contributes to the region's wellbeing. This article argues that Turkey-GCC cooperation develops in multiple dimensions and in a mutually beneficial manner, as the both actors share common and vested interests in many of the regional issues.
\end{abstract}

Keywords: Turkish Foreign Policy, Gulf Cooperation Council.

\section{Introduction}

In 2008, The Republic of Turkey became the first country that started a mechanism of strategic dialogue with the Gulf Cooperation Council (GCC). This event, though not much publicized in the international arena, was significant in terms of greater institutionalized collaboration mechanisms between the Middle East and The Republic of Turkey. It was also an important move for dialogue on cooperation in such fields as transport and energy security.

The GCC countries are amongst the wealthiest and most prosperous in the Middle East. Turkey, which is a "non-member Strategic Dialogue Partner" of the GCC, has also been a country of relative peace and stability compared to the rest of the region. In addition, Turkey has been one of the fastest growing economies over the last decade. Though Turkey is relatively resource-poor in terms of fossil reserves, it is an industrially developed economy where construction (residential and office buildings as well as infrastructure projects), manufacturing (textile, automotive among others) industries and services (such as tourism and financial services) are the main drivers of the economy.

With Turkey in the North and the GCC in the South, together these two zones constitute regions of relative prosperity and stability in the continuously troubled Middle East region, and their economic structures are complementing each other's lacking resources. The dynamic economic growth over the last decade (2003-2013) in Turkey and the GCC has been impressive, especially at a period of global economic recession 2009 onwards. Furthermore, Turkey's present special relationship with the GCC represents the growing importance attached to relations with

* Ph.D. Candidate at Bilkent University, Department of International Relations. 
countries in the Middle East since the Özal era (1983-1993). ${ }^{1}$ This special relationship should be seen in the context of Turkey's continuing intensification of its ties with other organizations in the Middle East, and in Asia through organizations such as the Organization of the Islamic Conference - OIC (to which Turkey is a member), and The League of Arab States - Arab League (to which Turkey is an observer non-member, only an observer state). Furthermore, Turkey is also playing a pivotal role in the North Atlantic Treaty Organization's (NATO) cooperation with the Gulf area through the Istanbul Cooperation Initiative - ICI (in which 4 out of the 6 GCC countries are participating) ${ }^{2}$ And cooperation with most of the other MENA countries are carried out within the framework of NATO's Mediterranean Initiative.

Important economic benefits seem to have already developed form a closer cooperation between Turkey and the countries of the GCC. This is an important incentive for continued cooperation while the issues relevant to the overall political and security developments of the Middle East region also remain at the forefront of this cooperation mechanism. One such challenge, at least perceived so in the eyes of the international community, is the concerns regarding the suspect civilian nuclear program of Iran. Another challenge is recent important socio-political developments in the Middle East, i.e. the Arab Spring. The concerns over energy transport security and choke points such as the Strait of Hormuz will also be important items on the agenda of this cooperation. All of these seem to suggest that cooperation is likely to increase between Turkey and the GCC. Though not having a shore to the Gulf, nor being resource rich, the Kingdom of Morocco and the Hashemite Kingdom of Jordan are also considering GCC membership. This suggests in part some of the relative success that the GCC has had in comparison to many other regional organizations.

\section{History}

The Six countries that are members of The Cooperation Council for the Arab States of the Gulf (also known in short as the Gulf Cooperation Council - GCC) represent some of the wealthiest and most prosperous countries, cities, and places in the Middle East. These countries are United Arab Emirates (UAE), The Kingdom of Bahrain, The Kingdom of Saudi Arabia (KSA), The Sultanate of Oman (Oman),

1 Although Özal served as Deputy Prime Minister before 1983, The Özal era is generally accepted as the years when he served as a popularly elected Prime Minister in the 1983 post-coup free elections, into his presidency until his death in 1993. Therefore, the 10 years between 1983-1993 will be the time-frame accepted for our purposes.

2 Diriöz, Ali Oğuz, "NATO's Policy and Institutional Programs towards the Middle East”, Middle East Analysis, April' 12, Vol. 4, Issue 40, pp. 49-57. 
The State of Qatar, and Kuwait. ${ }^{3}$ All the countries are Arab monarchies that have shores to the Persian Gulf (a.k.a. Arab Gulf or Gulf of Basra). Most of these countries are among the richest in the world's fossil fuel reserves such as oil and natural gas. For instance, Saudi Arabia, Kuwait, United Arab Emirates, and Qatar are also members of The Organization of the Petroleum Exporting Countries - OPEC. ${ }^{4}$ Bahrain and Oman, are also petroleum and natural gas exporting countries, although not at the same scale as the other four GCC-member countries. It is also important to bear in mind that, many of these countries have Sunni rulers with sizable Shiite minorities, or in the case of Bahrain a Shiite majority. Another exception is the Sultanate of Oman, where the Sultan and the majority of the population adhere to Ibadi Islam; which is distinct from Sunni and Shia Islam.

Today, the GCC has a Defense Agreement, an internal Customs Union and Common Market, and the countries are exploring other means of cooperation on the economic, military, and strategic, as well as the monetary levels. It is effectively a regional political, economic, and military alliance made up by the six member states. Like the European Union (EU), it has Turkey as an associate; is currently holding talks for enlargement (with Morocco and Jordan), and is planning for the prospect of achieving a monetary union. A Customs Union and a Common Market, where there would be a free movement of goods and of people is mostly in place.

\section{Political Meaning of "The Gulf"}

At this point, it is important to note the different ways various nations or group of nations refer to "the Gulf", depending on their national preferences or policies. In this context, we also see sometimes that the term "Persian Gulf" is not universally used. The "Halic/Halidj" or the "Gulf" word in the GCC refers to what is widely known in the English speaking world as the Persian Gulf, which is the narrow sea that lies between Iran and the Arabian peninsula, from Basra to the Strait of Hormuz. However, this term is more widely used because since the time of the Persian Empire of antiquity Iranians had referred to it as the Persian Gulf and that was the name adopted by most Western states. In Turkish, it is referred to as the "Basra Körfezi" which means the Gulf of Basra, an expression from the Ottoman times in reference to the province of Basra. Finally, most Arab countries, and countries of the GCC itself refer to it as the Arab Gulf, thus contesting the name of "Persian Gulf." The difference in terminology highlights Persian and Arab claims and rivalry in the region. For our purposes, the terms "Persian Gulf", "Arab Gulf", or "Gulf of Basra" would be used interchangeably for one and same geographic region at the Northeast of the Arabian Peninsula, and South of Iran.

3 GCC Official Website, English version (http://www.gcc-sg.org/eng/index.html), Last accessed: 29 March 2013, 13:05 GMT- 5.

4 OPEC Official Website, English version (http://www.opec.org/opec_web/en/about_ us/25.htm), Last accessed: 29 March 2013, 14:07 GMT- 5. 


\section{Origins}

The GCC is a very dynamic and influential regional organization nowadays. Yet, it is a relatively recent organization, as it was founded in 1981 against the backdrop of the Islamic Revolution in Iran, and the subsequent Iran-Iraq War ${ }^{5}$ The treaty establishing the GCC was signed in the city of Abu Dhabi, UAE on May 25th 1981. Some say that its purpose was to effectively allow the founding countries to have a form of alliance, not only to deter potential threats, but also to stay out of the Iran-Iraq War of the 1980s. The GCC is a regional alliance that goes beyond a simple economic union as there is a two-brigade "Peninsula Shield Force" that was created in 1984 following the ministers of defense meeting. Following the liberation of Kuwait from the Iraqi occupation in 1991, the military security was still the immediate concern of the GCC. But the only time the Peninsula Shield Force was actively deployed was in 2011 to Bahrain (in the context of the Arab Spring), in order to bring under control the social uprising of the majority Shia population against the Sunni rulers in Bahrain. ${ }^{6}$ Aside from assisting Bahrain to keep the uprising under control, the intervention was at the same time a political message aimed at deterring any foreign intervention by other powers of the region. Hence, security and geopolitics were at the origins of the GCC. The GCC Joint Defense Agreement was signed in Manama on December 2000, effectively bringing a collective defense mechanism to the existing GCC structure. ${ }^{7}$ Dialogue on security issues, particularly energy security and the safe and secure transportation of energy, as well as the security of the strategic choke point of the Strait of Hormuz, remain a top item on the agenda of the GCC States. This being said, however, much of the GCC's success is often visible in the realm of economy and trade.

\section{Evolution}

Today, the GCC countries cover a total area of 2,423,300 $\mathrm{km}^{2}$, and have a total combined population of approximately 45.9 million people. The countries of the GCC possess some of the richest reserves of oil and natural gas in the world. For example, with some 264.52 billion barrels of proven crude oil reserves, Saudi Arabia is the country with the world's largest proven reserves of petroleum. ${ }^{8}$ Another

5 BBC News: Middle East Country Profile, GCC, 15 February 2012 (http://news. bbc.co.uk/2/hi/middle_east/country_profiles/4155001.stm), Last accessed: 27 March 2013.

6 Globalsecurity.Org: GCC, (http://www.globalsecurity.org/military/world/gulf/gcc. htm), Last accessed: 30 March 2013, 14:45 GMT- 5.

7 GCC Official Website, English version (http://www.gcc-sg.org/eng/index8409. html?action=Sec-Show\&ID=49), Last accessed: 29 March 2013, 13:05 GMT- 5.

8 Diriöz, Ali Oğuz, "Saudi Arabia's Foreign Policy and Relations with the Countries of the Region”, Middle East Analysis, March'12, Vol.4, Issue 39, pp. 94-100. 
example is Qatar with some 890 trillion cubic feet of proven natural gas reserves. Qatar is the third largest country in the world in terms of proven reserves of natural gas, and the single largest exporter of liquefied natural gas (LNG). ${ }^{9}$ Incidentally, the mammoth size Qatar North field is adjacent to Iran's southern Pars fields and hence issues concerning the maritime line between these two countries and the related issues of territorial waters, exclusive economic zones (EEZ), and continental shelves might very likely be a potential source of disagreement between Iran and Qatar, in the future. The Gulf has a history of territorial claims and disputes, such as the Abu Musa Island between Iran and UAE, as well as the past disagreement over the Hawar Island between Qatar and Bahrain.

Though security and geopolitics are still very important for the GCC, gradually increased economic and cultural cooperation is coming to the forefront in the organization's activities. Free trade and free movement are important to the success of the GCC. The combined GDP of the six countries amount to an astonishing level of 1.37 trillion USD (roughly 29,900 USD per capita). A successful implementation of a customs union in January 2003 and the launching of a common market in 2008 are examples of deepening cooperation at the economic level. GCC citizens can freely travel amongst each other without a visa. There are also ongoing discussions for monetary union and for forming a single currency similar to the Euro, although UAE and Oman would not be part of the monetary union. ${ }^{10}$ The GCC has been also an important forum for cooperation, collaboration and peaceful resolution of disputes in the region.

\section{The "Friendship Bridge" between Qatar and Bahrain}

An example of peaceful resolution of disputes within the GCC is the settlement of the dispute between Qatar and Bahrain regarding the islands of Hawar located between Bahrain and the northwest coast of Qatar. Though tensions had increased sporadically in the 1980s and even the 1990s over the islands and some other territorial claims were made, the case was taken to the International Court of Justice (ICJ) in The Hague, Netherlands. The ICJ's decision in 2001 was that the islands were to be under Bahrain's jurisdiction. Both countries respected the decision of the ICJ, and to overcome past differences, announced in 2008, a few years following the ICJ's decision, their intention to begin the construction of a "Friendship Bridge" (of the Qatar Bahrain Causeway) that would run some 40 kilometers from Qatar to Bahrain. To this date, this project has not yet started; however, both countries aim completion before the 2022 FIFA World Cup in Qatar. If completed, it

9 U.S. Energy Information Administration, Country Analysis Brief: QATAR, Full Report Last Updated on January 30th, 2013 (http://www.eia.gov/countries/analysisbriefs/Qatar/qatar.pdf), Last accessed: 30 March 2013.

10 GCC Official Website, English version (http://www.gcc-sg.org/eng/index.html), Last accessed: 29 March 2013. 
would be even longer than the existing $26 \mathrm{~km}$ King Fahd Causeway that connects the island of Bahrain to Saudi Arabia in the mainland of the Arabian Peninsula. King Fahd Causeway was opened to the public in 1986, and has been the only land connection from Bahrain to the Arabian Peninsula. Bahrain in principle is favorable to have a second connection, but cites financial difficulties as cause for delay of the start of construction. ${ }^{11}$ The 2011 social upheaval of the Shiite majority in this country, and the troops sent by GCC countries certainly also played a role in the delay of the project.

The success of the aforementioned example can be attributed in part to the institutional mechanisms of the GCC that made it more attractive and advantageous for its members to cooperate rather than focus on past differences. Yet, the same could not be said with disputes over islands in the Gulf between Iran and the UAE. And to make matters more complicated, the disputes between Iran and the Gulf countries are not only confined to the question of the islands (Abu Musa, Greater Tunb, and Lesser Tunb) but also, statements by some high level Iranian officials noting that Bahrain was a province of Iran in the past. ${ }^{12}$ In various periods in history, different Iranian officials, going back to the Shah's time, stated that Bahrain is a province of Iran. Such statements by Iranian officials, although occurring sporadically, question the respect they would have on the sovereignty of Bahrain; especially when there is an uprising against the ruler of Bahrain. These provincial claims should be taken seriously as the last time a GCC member was proclaimed a province, it was actually invaded (Iraq had declared Kuwait its province and invaded Kuwait in 1990). In this connection, an ongoing issue of potential confrontation between UAE and Iran concerns the Abu Musa Island in the Gulf. Iran has occupied the island since 1971, but the tiny island came back to the attention of the international community when Iranian president Ahmedinejad decided to visit the island in April 2012. ${ }^{13}$ This move was probably done in an effort to divert attention away from domestic protests and increase national sense of unity, as well as to send a message about growing Iranian influence in the "Persian Gulf." Though the island itself is tiny with around 2000 inhabitants, it could be the sign of future trouble in the international waters and maritime lines of the Gulf.

11 Diriöz, Ali Oğuz, "Turkey-Gulf Cooperation Council Relations", Middle East Analysis, June'09, Vol. 1, Issue 6, pp. 77-81.

12 Today's Zaman, "Bahrain rejects Iran comments on sovereignty", 23 February 2009, (http://www.todayszaman.com/newsDetail_getNewsById.action?load=detay\& link=167742), Last Accessed: 31 March 2013, 22:45 GMT- 5.

13 Erdbrink, Thomas "A Tiny Island is Where Iran Makes a Stand," April 30, 2012, New York Times, Print Edition on 1 May 2012 Pg. A1. (http://www.nytimes. com/2012/05/01/world/middleeast/dispute-over-island-of-abu-musa-unites-iran. html?_r=0), Last Accessed: 30 March 2013, 18:20 GMT- 5. 


\section{Current Issues between Turkey and GCC}

Turkey, in 2008, has been the first country to enter into a Strategic Dialogue Mechanism with the GCC. The US, which had strong bilateral and multilateral political, economic and defense ties and dialogue with the GCC initiated its more formal institutional relations with the establishment of the GCC-US Strategic Cooperation Forum in March 2012. This is different than the GCC membership talks with Morocco and Jordan, as both countries continue talks for future membership; Turkey does not have any such aspiration. This is significant because for the first time, the GCC has entered with a third country, into a relationship based on formal and institutionalized mechanisms of strategic cooperation, with notable regular activities such as periodic meetings of foreign ministers, among other forms of cooperation. After the mid 1960s, in response to its allies' lukewarm reaction of the Cyprus issue, Turkey had already started diversifying its international relations. With the Özal era of late 1980s-early 1990s, Turkey had intensified its dialogue with its neighbors and in particular with countries of the Middle East. Before the 1980s, Turkey was less involved in the Middle East. For example, Turkey displayed a low key participation in the Organization of the Islamic Conference (OIC) when it was first founded in 1969. By contrast, today Turkey's policy towards the Middle East, including the GCC, has become more active. For instance, the Secretary General of the OIC, from 2005 to 2013, was a Turkish citizen, namely; Prof. Dr. Ekmeleddin İhsanoglu. ${ }^{14}$ In that respect, Turkey is overtly putting greater emphasis to cooperation and collaboration with the Middle East. And the GCC is at the forefront of this increased cooperation.

Another example of growing importance attributed to the countries in the GCC could be seen by the growing collaboration efforts between NATO and the GCC. NATO's cooperation in the Middle East through the Mediterranean Dialogue program, and the Istanbul Cooperation Initiative - ICI (to which 4 out of the 6 GCC countries are participating ${ }^{15}$ is a reflection of the growing importance attached by Turkey and NATO allies to the Middle East region. While Saudi Arabia is conspicuous with its absence in such collaborations, Saudi Arabia has important bilateral relations with the United States, which is essentially the locomotive of NATO. Therefore, Turkey-GCC cooperation has multiple dimensions and vast arrays of potential multilateral cooperation that are not only limited to Turkey's bilateral relations with each of the six GCC countries.

Turkey-GCC cooperation is one that is of multiple dimensions; political/geopolitical, economic, and cultural. Turkish then Foreign Minister and current Prime Minister, Prof. Dr. Ahmet Davutoglu, summarized these three dimensions of the

14 Organization of the Islamic Conference (OIC) Official Website in English, Section on the Secretary General (http://www.oic-oci.org/page_detail.asp?p_id=58), Last Accessed: 23 March 2013, 10:20 GMT- 5.

15 Diriöz, Ali Oğuz, "NATO's Policy and Institutional Programs towards the Middle East” Middle East Analysis, April'12, Vol. 4, Issue 40, pp. 49-57. 
Turkey-GCC strategic dialogue mechanism, following a Turkey-GCC meeting in Istanbul in July 2009: "This meeting, in many respects is a first. Because the GCC is for the first time creating a strategic dialogue mechanism of this dimension with a single country. Indeed, there exists a real historic friendship bridge between our peoples...I would like to draw your attention to three dimensions of our works and mechanisms: First one is the political and strategic dimension...A high level political and strategic dialogue is commencing with these meetings. Previously we enjoyed excellent bilateral relations with each of these states. This time, we are creating this mechanism between Turkey and GCC at the institutional level. Second dimension is the economic field...We need to conclude the negotiations on the Free Trade Agreement as soon as possible. Third dimension is the cultural one". ${ }^{16}$

Since the initiation of the strategic dialogue between Turkey and the GCC, the trade flow has been steadily increasing as Turkey received some 30 billion USD worth of investment since 2001 from the Gulf region. Furthermore, in 2011 alone, the annual trade volume between Turkey and the Gulf region increased by over $36 \%$. These numbers are all the more significant because they were achieved at a time when Europe was hit by a global economic crisis since 2009. In addition, the social uprisings and events known as the Arab Spring also started in 2011. Hence, the regions surrounding Turkey and the GCC were increasingly unstable since the initiation of the Strategic Dialogue Mechanisms, and by contrast, trade and overall economic activity between Turkey and the Gulf significantly increased since the initiation of these strategic dialogue mechanisms despite these circumstances. Therefore, one can truly talk of the critical timing and win-win result of this increase in cooperation. ${ }^{17}$

In spite of many contrasts and differences, Turkey and the GCC countries can look toward a common future of greater cooperation due to common historic, cultural, and religious ties that are unifiers to the common history of their peoples. In times of global economic recession, the economic need for cooperation is evidently important. Additionally, growing security challenges on critical choke points such as from piracy in the Gulf of Aden, along the Horn of Africa, and fears of the Strait

16 Remarks made by Turkish then Foreign Minister Davutoğlu during the press conference following the Turkey-GCC Economic High Level Strategic Dialogue, 1st Meeting of the Foreign Ministers, 8 July 2009, Istanbul (TC-KİK Ekonomik Yüksek Düzeyli Stratejik Diyalog I. Dışişleri Bakanları Toplantısı sonundaki basın toplantısı sonunda Dışişleri Bakanı Sn. Davutoğlu'nun ifadeleri: 8 Temmuz 2009, İstanbul) (http://www.mfa.gov.tr/turkiye-korfez-isbirligi-konseyi-ekonomik-yuksekduzeyli-stratejik-diyalog-i_-disisleri-bakanlari-toplantisi-sonrasinda-yapilan. tr.mfa), Last Accessed 24 March 2013, 9:10 AM GMT- 5.

17 The figures given in a speech given by Turkish Foreign Minister Davutoğlu during the press statement following the Turkish-GCC Foreign Ministers Meeting, 28 January 2012, in Istanbul. (http://www.turkishnews.com/en/content/2012/01/29/ foreign-ministers-of-turkey-and-gcc-countries-conclude-meeting-in-istanbul/), Last Accessed 29 March 2013, 16:30 GMT- 5. 
of Hormuz closing due to tensions related to Iran's nuclear program, and the still unresolved crisis in Syria, are other items on the top of the agenda of Turkey and the GCC countries. Though there is more cooperation between Turkey and GCC on strategic and regional issues, some differences of approach may also exist. Reactions to the Arab Spring may be varied. Even within the GCC there may be varied or diverging approaches to key issues that may have an impact on the security and the stability of the GCC countries, as had been seen since the onset of the Arab Spring. In particular policies of Qatar diverged from that of the other GCC members led by Saudi Arabia on the issue of reaction to the developments in Egypt and to the Muslim Brotherhood organization, which at one point led to rupture of diplomatic relations between these GCC countries. The ties were subsequently restored and the differences were papered over. Also, the reaction by Western countries, including the US, to each case appears to be varied as well. For instance, reaction to Libya was different than the reaction to Bahrain, which in turn was different than the reaction to the events in Syria. Most of the time, countries are caught between their interests and values. Secure transportation of energy is likely to remain an important item for Turkey, which is an important transit corridor between supplier states and consumer states, and for the GCC, which are among the main suppliers.

\section{Relations with Iran}

Relations with Iran are considered to be one of the leitmotifs of the Turkey-GCC cooperation. The nuclear program of Iran, which is claimed to be not transparent and not properly conducted under the inspection of the International Atomic Energy Agency (IAEA), is accompanied by a program of ballistic missiles. Many countries in the West find the intentions of Iran suspicious. Many countries in the Gulf are also concerned of Iran's intentions, and could possibly be driven to initiate civilian nuclear programs of their own. This in turn might begin a dangerous race and nuclearization of the region.

Turkey has not entered into a direct conflict with Iran for centuries, even though they have had competing interests from time to time. Both countries have been careful in making sure that competition does not turn into confrontation. Even though Iran cuts natural gas supplies to Turkey from time to time for "technical" reasons, the overall relationship remains relatively stable. The Gulf countries, which are sharing maritime borders with Iran, also try to avoid entering into a direct confrontation with Iran. Yet their relations have at best been only cordial. These rivalries are amid perceived fears that Iran aims to dominate the Middle East and is in search of a regional hegemony. ${ }^{18}$ The only countries in the region

18 Henderson, Simon and Scheinmann, Gabe, "Risking the Finlandization of the Persian Gulf" The Washington Institute for Near East Policy, Policy Analysis, 19 March 2013, (Published in Wall Street Journal) (http://www.washingtoninstitute. 
that are individually large and populous enough to be comparable with the Iranian influence are Egypt, Turkey, and Saudi Arabia. Despite the increasing cooperation between Turkey and the GCC, after each meeting both parties go to great lengths to state that their cooperation is not directed against third parties.

Turkey's cooperation with the GCC in all fields, including strategic aspects, is a symbol of further integration in the Middle East. This could be of mutual interest as Turkey has strong economic and political interests for having good relations with all sides concerned with the security and stability of the Gulf. ${ }^{19}$ For the sake of peace and stability in the region, more transparency of the Iranian nuclear program via IAEA inspections could help enhance mutual trust in the region. A diplomatic solution to the concerns raised on Iran's nuclear program would further build mutual confidence in the Gulf region as it is deemed increasingly suspect when a country that sits on one of the largest oil reserves in the world and the second largest natural gas reserve, is conducting a nuclear program that is not transparent, and that is also accompanied with a ballistic missiles program. Any potential conflict can be devastating for both the region and the global economy, as the region is dependent on a single choke point, namely the Strait of Hormuz, for the flow of most of the oil and natural gas out of the region to the global markets.

\section{The Strait of Hormuz}

The Gulf of Basra is the main artery of the global oil and LNG markets. All the tanker vessels from this area have to pass through the Strait of Hormuz, which is not navigable for tankers in all of its locations. The geographic location of the Strait of Hormuz is described often as a dagger on a throat, as it literally looks like a dagger that at any time could cut the choke point. Countless evaluation of risk scenarios concerning the Strait of Hormuz can be generated on a daily basis. The dominant scenarios today include a spillover of the Syrian crisis to a larger regional Shia-Sunni conflict, or a unilateral attack by Israel to prevent Iran from achieving nuclear capabilities. One of the prevalent scenarios of potential confrontation foresees a crisis spurred due to the maritime border and island disputes between Iran and one or more of the GCC countries. The actual situation in the face of the closing of the Strait of Hormuz might be even grimmer than what could be anticipated. Some options in the face of the crisis scenarios include attempts to diversify the energy routes by completing new pipelines such as the one between Abu-Dhabi and Fujairah in the UAE, or releasing of the strategic reserves (which were successful during the crisis in Libya, as foreseen by new International Energy Agency (IEA) regulation. This regulation stipulates that countries should stock

org/policy-analysis/view/risking-the-finlandization-of-the-persian-gulf), Last Accessed 29 March 2013, 23:20 GMT-5.

19 Başkan, Birol, “Turkey-GCC Relations: is there a Future?", Insight Turkey Vol. 13 / No. 1 / 2011 pp. 159-173. 
90 days of oil supply). Yet some estimate that nearly 40 percent of the world's daily energy needs flow from the Strait of Hormuz.

The geographical and political features of the Strait of Hormuz make it all the more sensitive in light of potential events. This strategic choke point is, at the narrowest point around the Musandam Peninsula in the south and Iran in the North, is only 34 nautical miles wide. Of that width, only 2 nautical miles are navigable if a 2 mile buffer margin were left. To make matters even more complicated, the Musandam Peninsula and the city of Ras Musandam belong to the Sultanate of Oman, but are separated from the rest of Oman by the UAE. This situation is effectively making the administration of the region physically detached from the rest of Oman, and making GCC cooperation and bilateral cooperation between Oman and UAE all the more important for the sake of both countries, as well as that of the global economy. Needless to mention that the disputed island of Abu Musa, between Iran and the UAE, lies at the southwest of the Musandam Peninsula, and south of the maritime navigation lines.

While countries such as the United States, which are less dependent on Middle Eastern oil, would be less affected and primarily be price wise sensitive to the event. Other countries and regions like Japan and the Asia-Pacific, not to mention Europe and Turkey, would be some of the most adversely affected economies. As they are more vulnerable in the face of such a shut-out, and astronomical rises in prices of oil, to a margin considerably above its recent level of approximately 110 USD for Brent crude oil in March 2013 (which fell 80 USD in November 2014), to well above the historical height of 147 USD. Turkey and GCC countries such as Qatar are exploring alternative ways to be interconnected through pipelines, thus reducing the ongoing traffic through The Strait of Hormuz.

\section{Conclusion}

Turkey and the GCC countries share common historic, cultural, and religious ties that are unifiers for their peoples. Furthermore, Turkey and the Gulf countries have complementary economies. The former possesses a strong industry, manufacturing a wide array of different industrial products, having a vast and varied services industries that range from tourism to technical know-how in natural gas operations. Turkey also has one of the strongest construction companies in the entire region, with contractors capable of implementing large scale infrastructure, industrial and residential projects. Of course these are accompanied with strong human capital in terms of technical know-how. The countries of the GCC, on the other hand have rich energy resources, and considerable financial capitals, including a wide array of Islamic Banking portfolio and sovereign wealth funds, that are capable of realizing large scale investments in mega-projects. GCC countries, notably Qatar, are also hosting a series of important international events such as the 2022 FIFA World Cup. Hence there are great economic incentives for Turkey and the GCC to continue collaboration, and companies and investors from both sides will have great opportunities. In addition to the mutual benefits of economic 
cooperation, both Turkey and the GCC share the common desire and have the common interest of having peace and stability in the Middle East. With issues such as the Arab Spring, the Arab-Israeli disputes, the fragility of stability in Iraq, the events in Syria, and Iran's nuclear program (that is accompanied with a program of ballistic missiles), Turkey and the GCC countries would share common and vested interests in many of the regional issues as stability would be a pre-condition, a sine qua non, of continued international business in the region.

\section{Bibliography}

Başkan, Birol, "Turkey-GCC Relations: is there a Future?”, Insight Turkey Vol. 13/ No. 1/2011, pp. 159-173.

BBC News: Middle East Country Profile, GCC, 15 February 2012 (http://news.bbc. co.uk/2/hi/middle_east/country_profiles/4155001.stm), Last accessed: 27 March 2013 ,

Diriöz, Ali Oğuz, "NATO's Policy and Institutional Programs towards the Middle East”, Middle East Analysis, April'12, Vol. 4, Issue 40, pp. 49-57.

Diriöz, Ali Oğuz, "Saudi Arabia's Foreign Policy and Relations with the Countries of the Region”, Middle East Analysis, March'12, Vol.4, Issue 39, pp. 94-100.

Diriöz, Ali Oğuz, "Turkey-Gulf Cooperation Council Relations”, Middle East Analysis, June’09, Vol. 1, Issue 6, pp. 77-81.

Erdbrink, Thomas "A Tiny Island is Where Iran Makes a Stand," April 30, 2012, New York Times, Print Edition on 1 May 2012 Pg. A1. (http://www.nytimes. com/2012/05/01/world/middleeast/dispute-over-island-of-abu-musa-unitesiran.html?_r=0), Last Accessed: 30 March 2013, 18:20 GMT- 5.

GCC Economic High Level Strategic Dialogue, 1st Meeting of the Foreign Ministers, 8 July 2009, Istanbul (TC-KIKK Ekonomik Yüksek Düzeyli Stratejik Diyalog I. Dışş̧̧leri Bakanları Toplantısı sonundaki basın toplantısı sonunda Dışişleri Bakanı Sn. Davutoğlu'nun ifadeleri: 8 Temmuz 2009, İstanbul) (http://www.mfa. gov.tr/turkiye-korfez-isbirligi-konseyi-ekonomik-yuksek-duzeyli-stratejikdiyalog-i_-disisleri-bakanlari-toplantisi-sonrasinda-yapilan.tr.mfa), Last Accessed 24 March 2013,

GCC Official Website, English version (http://www.gcc-sg.org/eng/index.html), Last accessed: 29 March 2013, 13:05 GMT- 5.

Globalsecurity.Org: GCC, (http://www.globalsecurity.org/military/world/gulf/gcc. htm), Last accessed: 30 March 2013, 14:45 GMT- 5.

Henderson, Simon and Scheinmann, Gabe, "Risking the Finlandization of the Persian Gulf" The Washington Institute for Near East Policy, Policy Analysis, 19 March 2013, (Published in Wall Street Journal) (http://www.washingtoninstitute. 
org/policy-analysis/view/risking-the-finlandization-of-the-persian-gulf), Last Accessed 29 March 2013, 23:20 GMT-5.

OPEC Official Website, English version (http://www.opec.org/opec_web/en/ about_us/25.htm), Last accessed: 29 March 2013, 14:07 GMT- 5.

Organization of the Islamic Conference (OIC) Official Website in English, Section on the Secretary General (http://www.oic-oci.org/page_detail.asp?p_id=58), Last Accessed: 23 March 2013, 10:20 GMT- 5.

Today's Zaman, "Bahrain rejects Iran comments on sovereignty”, 23 February 2009, (http://www.todayszaman.com/newsDetail_getNewsById.action?load=detay\& link=167742), Last Accessed: 31 March 2013, 22:45 GMT- 5.

Turkish-GCC Foreign Ministers Meeting, 28 January 2012, in Istanbul. (http:// www.turkishnews.com/en/content/2012/01/29/foreign-ministers-of-turkeyand-gcc-countries-conclude-meeting-in-istanbul/), Last Accessed 29 March 2013, 16:30 GMT- 5.

U.S. Energy Information Administration, Country Analysis Brief: QATAR, Full Report Last Updated on January 30th, 2013 (http://www.eia.gov/countries/analysisbriefs/Qatar/qatar.pdf), Last accessed: 30 March 2013, 15:10 GMT- 5. 